\title{
Wybrane rodzinne uwarunkowania tożsamości społeczno-kulturowej studentów w wymiarze religijnym
}

\section{KEYWORDS}

socio-cultural identity, religion, students, family

\begin{abstract}
Mirosław Sobecki, Wybrane rodzinne uwarunkowania tożsamości społeczno-kulturowej studentów w wymiarze religijnym [Selected family conditions of the socio-cultural identity of students in the religious dimension]. Kultura - Społeczeństwo - Edukacja nr 2(20) 2021, Poznań 2021, pp. 7-25, Adam Mickiewicz University Press. ISSN 2300-0422, ISSN (Online) 2719-2717. DOI 10.14746/ kse.2021.20.1
\end{abstract}

The article contains selected results of research from spring 2020 among students of universities in Białystok. The author distinguished 9 types of socio-cultural identity in the religious dimension. He also made an attempt to establish a relationship between these types and selected features of the family environment. The following were used as independent variables: the level of parents' education, opinions of the surveyed students on the level of parents' religiosity and the relationship between the respondents and their parents in childhood and adolescence. The relationship between the number of children in the respondent's family and the type of social and cultural identity in the religious dimension were also analyzed.

Jest rzeczą oczywistą, że środowisko rodzinne w znaczącym stopniu kształtuje społeczne funkcjonowanie jednostki. Rodzina nie tylko jest miejscem pierwszych kontaktów społecznych dziecka, ale także jako pierwsza wprowadza je w świat kultury. Tej problematyce nauki społeczne poświęcały i poświęcają nadal wiele uwagi.

* ORCID: https://orcid.org/0000-0003-2127-1275. 
Dotyczy to również sfery tożsamości i tożsamości społeczno-kulturowej jednostki (Sobecki, 2016). Rodzina jest dla dziecka główną przestrzenią budującą społeczno-kulturowe identyfikacje, zapewniającą mu poczucie więzi i zaangażowania (Lopez, Huynh, Fuligni, 2011). Bardzo duże znaczenie w kwestii kształtowania tożsamości przez rodzinę ma nowa sytuacja, w której się znalazła, związana z intensywnością przemieszczania się i w efekcie funkcjonowania $\mathrm{w}$ transnarodowej przestrzeni społecznej (Danilewicz, 2011).

Tożsamość społeczno-kulturowa w trakcie socjalizacji pierwotnej kształtuje się głównie poprzez rodzinny przekaz tradycji i wartości kulturowych. Przekaz ten inaczej przebiega w środowisku stosunkowo jednolitym kulturowo, inaczej zaś na obszarze nacechowanym kulturowym zróżnicowaniem. Pionierem badań w tym zakresie w Polsce jest Jerzy Nikitorowicz. Już we wczesnych swoich pracach wyróżnił on cztery typy rodzin socjalizujących w warunkach zróżnicowania kulturowego opartego głównie na odrębnościach etnicznych i wyznaniowych (Nikitorowicz, 1994: 58-60).

Rodzina stanowi o początkach wychowania w sferze konfesyjnej (Hunsberger, Brown, 1984: 239-51). Problematykę znaczenia rodziny w wychowaniu religijnym znajdziemy w wielu publikacjach ks. Józefa Wilka (Wilk, 1987), m.in. w jego pracy Pedagogika rodziny (Wilk, 2016). Środowisko rodzinne często pełni znaczącą rolę w tożsamości religijnej człowieka także w późniejszych fazach jego życia. Według Leona Dyczewskiego rodzina, tworząc i rozwijając własny mikrosystem kulturowy, stanowi dla swoich członków naturalne środowisko do generowania właściwego tylko tej rodzinie systemu wartości, norm i wzorców zachowań (Dyczewski, 2003: 38 i nast.) Oczywiście możliwości rodziny w zakresie przekazu kultury są zróżnicowane oraz ograniczone. Wskazywał na to już Robert K. Merton, kiedy w swojej klasycznej pracy Teoria socjologiczna i struktura społeczna pisał, że rodzina jest „oczywiście najważniejszym pasem transmisyjnym, który służy przekazywaniu wzorców kulturowych następnemu pokoleniu", ale zaraz podkreślał, że „do bardzo niedawna pomijano jednak fakt, iż rodzina przekazuje przeważnie część kultury, dostępną warstwie społecznej i grupom, w których znajdują się sami rodzice" (Merton, 2002: 222). XXI wiek stawia nowe wyzwania wobec edukacji, także związane ze zmianami, jakie zachodzą w społecznościach lokalnych w życiu religijnym (Edgell, 2006: 1).

Niniejszy artykuł dotyczy tożsamości społeczno-kulturowej późnych adolescentów. Przyjmując za Antoniną Kłoskowską, że o pełnej tożsamości stanowią analizowane łącznie identyfikacja i walencja kulturowa (Kłoskowska, 1994) oraz uwzględniając trzy poziomy pomiaru w obrębie każdej z nich, wyodrębniono dziewięć teoretycznych typów tożsamości społeczno-kulturowej w wymiarze tożsamości religijnej. Graficznie zostały one zaprezentowane w tabeli 1. 
Tabela 1. Typy tożsamości społeczno-kulturowej w wymiarze religijnym z uwzględnieniem poziomu identyfikacji i walencji

\begin{tabular}{|l|l|c|c|c|}
\hline \multicolumn{2}{|c|}{} & \multicolumn{3}{|c|}{ Poziom walencji kulturowej w sferze religijnej } \\
\cline { 3 - 5 } \multicolumn{2}{|c|}{} & wysoki & przeciętny & niski \\
\hline \multirow{3}{*}{$\begin{array}{l}\text { Poziom identyfikacji tożsamościowej } \\
\text { w sferze religijnej }\end{array}$} & wysoki & Typ A* & Typ B & Typ C \\
\cline { 2 - 5 } & przeciętny & Typ D & Typ E & Typ F \\
\cline { 2 - 5 } & niski & Typ G & Typ H & Typ I \\
\hline
\end{tabular}

* Typy tożsamości:

A - tożsamość z wysokim poziomem identyfikacji oraz walencji kulturowej w sferze religijnej

B - tożsamość $\mathrm{z}$ wysokim poziomem identyfikacji i przeciętnym poziomem walencji kulturowej $\mathrm{w}$ sferze religijnej

C - tożsamość z wysokim poziomem identyfikacji i niskim poziomem walencji kulturowej w sferze religijnej

D - tożsamość z przeciętnym poziomem identyfikacji i wysokim poziomem walencji kulturowej w sferze religijnej

E - tożsamość z przeciętnym poziomem identyfikacji i przeciętnym poziomem walencji kulturowej w sferze religijnej

F - tożsamość z przeciętnym poziomem identyfikacji i niskim poziomem walencji kulturowej w sferze religijnej

G - tożsamość z niskim poziomem identyfikacji i wysokim poziomem walencji kulturowej w sferze religijnej

$\mathrm{H}$ - tożsamość z niskim poziomem identyfikacji i przeciętnym poziomem walencji kulturowej w sferze religijnej

I - tożsamość z niskim poziomem identyfikacji i niskim poziomem walencji kulturowej w sferze religijnej

W analizach wyników badań skoncentruję się w szczególności na typach skrajnych, które w tabeli oznaczone zostały literami A oraz I. Pierwszy z nich (typ A) grupuje osoby z silną identyfikacją religijną, czyli takie, które w każdym pytaniu dotyczącym poczucia przynależności do zbiorowości religijnych zaznaczyły odpowiedź zdecydowanie tak oraz jednocześnie wykazały się wysokim poziomem pozytywnych reakcji na eksponowane korelatywne atrybuty chrześcijańskiej tożsamości religijnej. Taki typ tożsamości można uznać za dojrzałą i pełną. Typ oznaczony literą I grupuje osoby, które ani nie czują się związane ze zbiorowością religijną, ani nie wykazują się nawet przeciętnym rozeznaniem w kulturze symbolicznej związanej z religią chrześcijańską. O takich badanych możemy powiedzieć, że są pozbawieni tożsamości religijnej.

W niniejszym tekście chciałbym zaprezentować niektóre wyniki badań przeprowadzonych wiosną 2020 roku w 500-osobowej grupie studentów białostockich uczelni. Wśród nich 280 osób to studenci Uniwersytetu w Białymstoku, reprezentujący następujące kierunki: pedagogika (145 osób), biologia (55) i ekonomia (80). Politechnika Białostocka była reprezentowana przez 120 osób studiujących informatykę. Z kolei na Uniwersytecie Medycznym zwrócono się z prośbą o udział w badaniach do 100 studentów (kierunek lekarski - 60 osób, logopedia - 40 osób).

W przeprowadzonych badaniach kontrolowano szereg zmiennych, które dotyczyły rodziny. Poniżej zaprezentuję niektóre z uzyskanych wyników. Rozpocznę od wykształcenia rodziców badanych studentów. 446 uczestniczących w badaniu studentów podało w kwestionariuszu ankiety wykształcenie swoich matek. Przed- 
stawione proporcje dotyczą tylko tych osób (tab. 2). Prawie połowa badanych (43,5\%) zadeklarowała, że ich matki ukończyły szkołę wyższą. Jedynie w znikomym odsetku (2,5\%) studenci, którzy udzielili odpowiedzi na to pytanie, wskazali na podstawowe wykształcenie matki. Matka co piątego z udzielających odpowiedzi studentów $(21,8 \%)$ zakończyła swoją edukację na poziomie zasadniczej szkoły zawodowej, a co trzeciego (33,3\%) - na poziomie szkoły średniej.

Przyjrzyjmy się proporcjom. Warto zwrócić uwagę na to, że wśród studentów, którzy zadeklarowali najniższe wykształcenie matek, odsetek osób z typem tożsamości ze słabą identyfikacją i walencją w sferze religijnej (typ tożsamości I) jest zdecydowanie najwyższy. Cechuje on co trzeciego badanego w tej grupie $(36,4 \%)$. Co interesujące, ten typ tożsamości dominuje także wśród studentów, którzy zadeklarowali ukończenie przez matki studiów wyższych. Blisko co piąty badany $(19,1 \%)$ wychowany przez matkę po studiach także plasuje się w grupie studentów ze słabą identyfikacją i walencją w sferze tożsamości religijnej. Zbliżone wyniki uzyskano w odniesieniu do studentów, którzy zadeklarowali wykształcenie matek na poziomie zasadniczej szkoły zawodowej oraz szkoły średniej. W tych grupach badanych dominującym był typ tożsamości z silną identyfikacją oraz przeciętną walencją (typ B). Jednak jedynie w niewielkim stopniu ustępował on typowi, który charakteryzuje współwystępowanie silnej identyfikacji i walencji w sferze religijnej (typ A). Dla obu zadeklarowanych poziomów wykształcenia matek (zasadnicze zawodowe i średnie) łączny odsetek badanych z typem tożsamości A bądź B sięga prawie 50\% (47,9\% - przy wykształceniu matki zasadniczym zawodowym oraz 45,6\% - przy wykształceniu matki na poziomie szkoły średniej). Warto zwrócić uwagę, że silna identyfikacja religijna łącznie ze słabą walencją zdecydowanie częściej cechuje studentów, których matki zakończyły edukację na szkole podstawowej $(18,2 \%)$ niż pozostałych (od 4,3\% do 7,5\%).

Przyjrzyjmy się teraz, jak przedstawia się rozkład typów tożsamości badanych w zależności od poziomu wykształcenia ojców. Na pytanie dotyczące wykształcenia ojca odpowiedzi udzieliło 443 badanych. W analizie uwzględniono tylko te osoby (tab. 3). Rozkład zasadniczo nie różni się od tego, który uwzględniał poziom wykształcenia matek. Jednak w kilku miejscach warto zwrócić uwagę na ustalone różnice. Pierwsza dotyczy rozkładu typów tożsamości w grupie studentów, których ojcowie posiadają jedynie podstawowe wykształcenie. Brak tu wyraźnej dominanty, czego potwierdzeniem jest też charakter najczęściej występującego w tej grupie typu tożsamości. Co piątego badanego, którego ojciec skończył tylko szkołę podstawową (20,0\%), cechuje występowanie typu tożsamości z przeciętną identyfikacją oraz przeciętną walencją kulturową w sferze religijnej. W przypadku badanych studentów, których ojcowie prezentowali wykształcenie na poziomie 
Tabela 2. Rozkład zdiagnozowanych typów tożsamości w zależności od wykształcenia matki badanego

\begin{tabular}{|c|c|c|c|c|c|c|c|c|}
\hline \multirow{3}{*}{$\begin{array}{l}\text { Typy tożsamości } \\
\text { badanych }\end{array}$} & \multicolumn{8}{|c|}{ Poziom wykształcenia matki } \\
\hline & \multicolumn{2}{|c|}{ podstawowe } & \multicolumn{2}{|c|}{$\begin{array}{l}\text { zasadnicze } \\
\text { zawodowe }\end{array}$} & \multicolumn{2}{|c|}{ średnie } & \multicolumn{2}{|c|}{ wyższe } \\
\hline & Liczba & $\%$ & Liczba & $\%$ & Liczba & $\%$ & Liczba & $\%$ \\
\hline $\begin{aligned} & \text { Typ A - } \text { silna identyfikacja } \\
& \text { i silna walencja } \\
& \text { w sferze religijnej }\end{aligned}$ & 1 & 9,09 & 21 & 22,34 & 33 & 22,45 & 33 & 17,01 \\
\hline 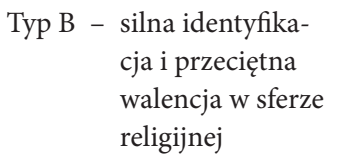 & 1 & 9,09 & 24 & 25,52 & 34 & 23,13 & 25 & 12,89 \\
\hline $\begin{array}{r}\text { Typ C - silna identyfikacja } \\
\text { i słaba walencja } \\
\text { w sferze religijnej }\end{array}$ & 2 & 18,18 & 4 & 4,26 & 11 & 7,48 & 14 & 7,22 \\
\hline $\begin{array}{c}\text { Typ D - } \text { przeciętna iden- } \\
\text { tyfikacja i silna } \\
\text { walencja w sferze } \\
\text { religijnej }\end{array}$ & 1 & 9,09 & 8 & 8,51 & 16 & 10,88 & 17 & 8,76 \\
\hline 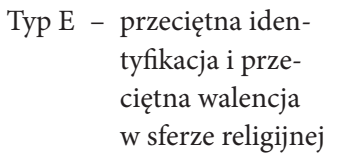 & 1 & 9,09 & 14 & 14,89 & 17 & 11,56 & 19 & 9,79 \\
\hline $\begin{aligned} \text { Typ F - } & \text { przeciętna iden- } \\
& \text { tyfikacja i słaba } \\
& \text { walencja w sferze } \\
& \text { religijnej }\end{aligned}$ & 0 & 0,00 & 7 & 7,45 & 6 & 4,08 & 27 & 13,92 \\
\hline $\begin{aligned} \text { Typ G - } & \text { słaba identy- } \\
& \text { fikacja i silna } \\
& \text { walencja w sferze } \\
& \text { religijnej }\end{aligned}$ & 0 & 0,00 & 4 & 4,26 & 4 & 2,72 & 6 & 3,09 \\
\hline $\begin{aligned} \text { Typ H - } & \text { słaba identyfika- } \\
& \text { cja i przeciętna } \\
& \text { walencja w sferze } \\
& \text { religijnej }\end{aligned}$ & 1 & 9,09 & 7 & 7,45 & 9 & 6,12 & 16 & 8,25 \\
\hline $\begin{aligned} \text { Typ I - } & \text { słaba identyfi- } \\
& \text { kacja i walencja } \\
& \text { w sferze religijnej }\end{aligned}$ & 4 & 36,37 & 5 & 5,32 & 17 & 11,56 & 37 & 19,07 \\
\hline
\end{tabular}

Źródło: badania własne 
szkoły zasadniczej zawodowej bądź średniej, dominujące typy były identyczne jak w przypadku podobnego statusu wykształcenia matek. Tutaj także prawie połowa badanych studentów lokowała się w grupie tożsamości z silną identyfikacją religijną oraz silną bądź przeciętną walencją kulturową w sferze religijnej. Wśród badanych, których ojcowie ukończyli szkołę wyższą, najczęściej występuje typ tożsamości religijnej oznaczony literą I, ze słabą identyfikacją oraz słabą walencją kulturową w sferze religijnej. Cechuje on prawie co czwartego badanego (23,1\%). To częściej zaledwie o 4 punkty procentowe niż w przypadku wyższego wykształcenia matek (19,1\%). Wynik analiz wykazuje wyraźne różnicowanie typów tożsamości badanych przez poziom wykształcenia ich rodziców. Okazało się, że współwystępowanie silnej identyfikacji ze zbiorowością religijną oraz wysokiego poziomu kompetencji w zakresie kultury symbolicznej tożsamościowej grupy odniesienia najczęściej ma miejsce wówczas, gdy rodzice badanego studenta ukończyli szkołę zasadniczą zawodową lub średnią.

Posiadanie przez rodziców wyższego wykształcenia znacznie zwiększa prawdopodobieństwo pojawienia się typu tożsamości oznaczonego literą I, w którym zarówno identyfikacja religijna, jak i świadomościowa reprezentacja symboli kulturowych związanych z grupą religijną (walencja) są na niskim poziomie.

Na zakończenie analizy dotyczącej roli wykształcenia rodziców w różnicowaniu występowania wyodrębnionych typów tożsamości przyjrzymy się, jaka jest częstotliwość pojawiania się wybranych typów tożsamości wśród badanych, kiedy uwzględnimy poziom wykształcenia obydwojga rodziców jednocześnie. Na wykresie 1 uwzględnione zostały charakterystyczne zestawienia wykształcenia rodziców, z jednej strony stosunkowo liczne, z drugiej wyraźnie różnicujące rozkład typów tożsamości społeczno-kulturowej w wymiarze religijnym.

Tożsamość typu A (silna identyfikacja występuje razem z silną walencją kulturową w sferze religijnej) najczęściej występuje w sytuacji, kiedy jeden z rodziców badanego dysponuje wykształceniem średnim, a drugi zasadniczym zawodowym. Cechuje ona co czwartego badanego z taką konfiguracją wykształcenia rodziców (27,6\%). Taki typ tożsamości zdecydowanie rzadziej - bo prawie dwukrotnie - cechuje studentów, których obydwoje rodzice są absolwentami szkół wyższych (16,3\%).

Gdy spojrzymy na skrajnie odmienny typ tożsamości (typ - I), w którym mamy do czynienia zarówno ze słabą identyfikacją ze zbiorowością religijną, ale także z niskim poziomem znajomości kryterialnych atrybutów tożsamościowych związanych z religią pochodzenia, to także dostrzegamy wyraźne zróżnicowanie. Taki typ tożsamości najczęściej występuje wśród badanych studentów, których obydwoje rodzice ukończyli szkołę wyższą, stwierdzono go u co 
Tabela 3. Rozkład zdiagnozowanych typów tożsamości w zależności od wykształcenia ojca badanego

\begin{tabular}{|c|c|c|c|c|c|c|c|c|}
\hline \multirow{3}{*}{$\begin{array}{l}\text { Typy tożsamości } \\
\text { badanych }\end{array}$} & \multicolumn{8}{|c|}{ Poziom wykształcenia ojca } \\
\hline & \multicolumn{2}{|c|}{ podstawowe } & \multicolumn{2}{|c|}{$\begin{array}{l}\text { zasadnicze } \\
\text { zawodowe }\end{array}$} & \multicolumn{2}{|c|}{ średnie } & \multicolumn{2}{|c|}{ wyższe } \\
\hline & Liczba & $\%$ & Liczba & $\%$ & Liczba & $\%$ & Liczba & $\%$ \\
\hline $\begin{aligned} & \text { Typ A - } \text { silna identyfikacja } \\
& \text { i silna walencja } \\
& \text { w sferze religijnej }\end{aligned}$ & 3 & 15,00 & 40 & 22,60 & 27 & 20,93 & 18 & 15,38 \\
\hline $\begin{aligned} \text { Typ B - } & \text { silna identyfika- } \\
& \text { cja i przeciętna } \\
& \text { walencja w sferze } \\
& \text { religijnej }\end{aligned}$ & 3 & 15,00 & 42 & 23,73 & 30 & 23,26 & 9 & 7,69 \\
\hline $\begin{aligned} & \text { Typ C - } \text { silna identyfikacja } \\
& \text { i słaba walencja } \\
& \text { w sferze religijnej }\end{aligned}$ & 3 & 15,00 & 9 & 5,08 & 9 & 6,98 & 10 & 8,55 \\
\hline 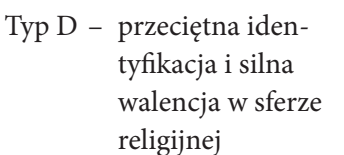 & 1 & 5,00 & 20 & 11,30 & 12 & 9,30 & 9 & 7,69 \\
\hline 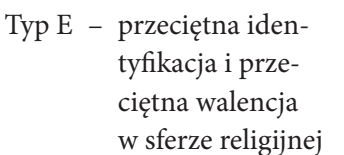 & 4 & 20,00 & 23 & 12,99 & 11 & 8,53 & 12 & 10,26 \\
\hline 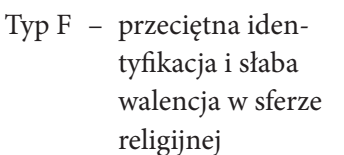 & 2 & 10,00 & 9 & 5,08 & 12 & 9,30 & 15 & 12,82 \\
\hline $\begin{aligned} \text { Typ G - } & \text { słaba identy- } \\
& \text { fikacja i silna } \\
& \text { walencja w sferze } \\
& \text { religijnej }\end{aligned}$ & 1 & 5,00 & 7 & 3,95 & 0 & 0,00 & 6 & 5,13 \\
\hline $\begin{array}{c}\text { Typ H - słaba identyfika- } \\
\text { cja i przeciętna } \\
\text { walencja w sferze } \\
\text { religijnej }\end{array}$ & 0 & 0,00 & 14 & 7,91 & 8 & 6,20 & 11 & 9,40 \\
\hline $\begin{aligned} \text { Typ I - } & \text { słaba identyfi- } \\
& \text { kacja i walencja } \\
& \text { w sferze religijnej }\end{aligned}$ & 3 & 15,00 & 13 & 7,34 & 20 & 15,50 & 27 & 23,08 \\
\hline Ogółem & 20 & 100,00 & 177 & 100,00 & 129 & 100,00 & 117 & 100,00 \\
\hline
\end{tabular}

Źródło: badania własne 
d) jedno - wykształcenie zasadnicze zawodowe, drugie - średnie

c) obydwoje - wykształcenie zasadnicze zawodowe

b) obydwoje - wykształcenie średnie

a) obydwoje - wykształcenie wyższe

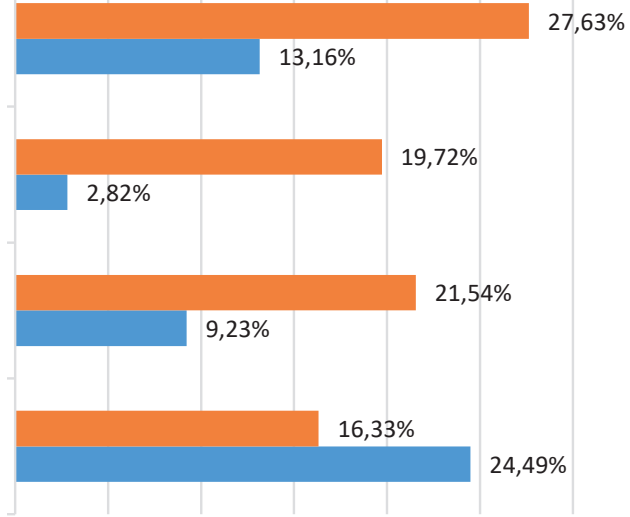

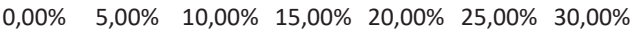

- Typ A - silna identyfikacja i silna walencja w sferze religijnej

- Typ I - słaba identyfikacja i walencja w sferze religijnej

Wykres 1. Rozkład skrajnych typów tożsamości (A, I) wśród badanych z uwzględnieniem wykształcenia obydwojga rodziców

Uwaga: odsetki nie sumują się do $100 \%$, ponieważ uwzględnione zostały wybrane tylko dwa typy tożsamości.

Źródło: badania własne

czwartego badanego z tej grupy (24,5\%). W grupie studentów, którzy zadeklarowali wykształcenie zasadnicze zawodowe obydwojga rodziców, tożsamość typu I występuje aż ośmiokrotnie rzadziej (2,8\%). Spośród pięciu badanych, których obydwoje rodzice zakończyli edukację na poziomie szkoły podstawowej, tylko u jednego wystąpił typ tożsamości z niską identyfikacją i walencją kulturową $\mathrm{w}$ sferze religijnej.

Kolejnym czynnikiem związanym z rodziną, którego znaczenie dla tożsamości religijnej próbowano ustalić, była homogeniczność konfesyjna rodziny. Zdecydowana większość badanych (344 osoby - 75\%) zadeklarowała, że zarówno matka, jak i ojciec przed zawarciem związku małżeńskiego byli katolikami. 30 badanych (6,6\%) pochodziło z rodzin jednolitych wyznaniowo, w których z kolei obydwoje rodzice zawierali małżeństwo jako prawosławni. Nieco liczniejsza grupa 41 badanych studentów $(9,1 \%)$ pochodzi z rodzin, w których małżonkowie różnili się wyznaniem przed zawarciem związku małżeńskiego. Rozkład typów tożsamości wśród badanych pochodzących z tych trzech kategorii rodzin prezentuje tabela 4 .

Jeżeli przyjrzymy się otrzymanym wynikom, to przede wszystkim daje się zauważyć zbliżony rozkład typów tożsamości w rodzinach jednolitych wyznaniowo, bez względu na to, czy rodzice przed zawarciem małżeństwa byli katolikami, 
Tabela 4. Rozkład wyodrębnionych typów tożsamości w wymiarze religijnym uwzględniający wyznanie rodziców badanych studentów przed zawarciem związku małżeńskiego

\begin{tabular}{|c|c|c|c|c|c|c|}
\hline \multirow{2}{*}{ Typy tożsamości } & \multicolumn{2}{|c|}{$\begin{array}{l}\text { Matka i ojciec- } \\
\text { katolicy }\end{array}$} & \multicolumn{2}{|c|}{$\begin{array}{l}\text { Matka i ojciec - } \\
\text { prawosławni }\end{array}$} & \multicolumn{2}{|c|}{$\begin{array}{l}\text { Matka i ojciec- } \\
\text { różne wyznania }\end{array}$} \\
\hline & Liczba & $\%$ & Liczba & $\%$ & Liczba & $\%$ \\
\hline $\begin{aligned} & \text { Typ A - } \text { silna identyfikacja } \\
& \text { i silna walencja } \\
& \text { w sferze religijnej }\end{aligned}$ & 76 & 22,09 & 8 & 26,67 & 5 & 12,20 \\
\hline $\begin{array}{c}\text { Typ B - } \\
\text { silna identyfika- } \\
\text { cja i przeciętna } \\
\text { walencja w sferze } \\
\text { religijnej }\end{array}$ & 69 & 20,06 & 8 & 26,67 & 4 & 9,76 \\
\hline $\begin{aligned} \text { Typ C - } & \text { silna identyfikacja } \\
& \text { i słaba walencja } \\
& \text { w sferze religijnej }\end{aligned}$ & 19 & 5,52 & 3 & 10,00 & 6 & 14,63 \\
\hline $\begin{aligned} \text { Typ D - } & \text { przeciętna iden- } \\
& \text { tyfikacja i silna } \\
& \text { walencja w sferze } \\
& \text { religijnej }\end{aligned}$ & 40 & 11,63 & 2 & 6,67 & 1 & 2,44 \\
\hline $\begin{aligned} \text { Typ E - } & \text { przeciętna iden- } \\
& \text { tyfikacja i prze- } \\
& \text { ciętna walencja } \\
& \text { w sferze religijnej }\end{aligned}$ & 38 & 11,05 & 5 & 16,67 & 5 & 12,20 \\
\hline $\begin{aligned} \text { Typ F - } & \text { przeciętna iden- } \\
& \text { tyfikacja i słaba } \\
& \text { walencja w sferze } \\
& \text { religijnej }\end{aligned}$ & 26 & 7,56 & 1 & 3,33 & 8 & 19,51 \\
\hline $\begin{aligned} \text { Typ G - } & \text { słaba identy- } \\
& \text { fikacja i silna } \\
& \text { walencja w sferze } \\
& \text { religijnej }\end{aligned}$ & 11 & 3,20 & 0 & 0,00 & 1 & 2,44 \\
\hline $\begin{aligned} \text { Typ H - słaba identyfika- } & \\
& \text { cja i przeciętna } \\
& \text { walencja w sferze } \\
& \text { religijnej }\end{aligned}$ & 27 & 7,85 & 2 & 6,67 & 1 & 2,44 \\
\hline $\begin{aligned} \text { Typ I - } & \text { słaba identyfi- } \\
& \text { kacja i walencja } \\
& \text { w sferze religijnej }\end{aligned}$ & 38 & 11,05 & 1 & 3,33 & 10 & 24,39 \\
\hline Ogółem & 344 & 100,00 & 30 & 100,00 & 41 & 100,00 \\
\hline
\end{tabular}

Źródło: badania własne 
czy prawosławnymi. Typ tożsamości A, z silną identyfikacją oraz silną walencją kulturową w wymiarze religijnym, jest na pierwszym miejscu co do częstotliwości występowania u studentów $\mathrm{z}$ rodzicami prawosławnymi (26,7\%), podobnie jak w przypadku studentów, których rodzice są katolikami (22,1\%). Jednak typy tożsamości z silną identyfikacją oraz silną bądź przeciętną walencją (typ A oraz typ B) grupują ponad połowę badanych dzieci prawosławnych rodziców $(53,3 \%)$, to o ponad 11 punktów procentowych więcej niż w przypadku badanych pochodzących z rodzin z obydwojgiem rodziców katolików $(42,1 \%)$. Warto także zwrócić uwagę, że typ tożsamości I, z niskim poziomem identyfikacji i walencji, ponad trzykrotnie rzadziej pojawia się u badanych pochodzących z rodzin prawosławnych $(3,3 \%)$ niż z katolickich $(11,1 \%)$.

Zgodnie z przewidywaniami zupełnie inny obraz dotyczy badanych pochodzących $\mathrm{z}$ rodzin mieszanych wyznaniowo. W tym przypadku największą część badanych cechuje typ tożsamości I, ze słabą identyfikacją i walencją. Dotyczy on co czwartego studenta $\mathrm{z}$ tej grupy $(24,4 \%)$. Drugi co do częstości występowania jest typ (F), w którym słabej orientacji w dziedzictwie religijnym towarzyszy przeciętna siła identyfikacji (19,5\%). Taki typ tożsamości jest wśród badanych pochodzących $\mathrm{z}$ rodzin mieszanych ponad dwukrotnie częstszy niż u badanych $\mathrm{z}$ rodzin jednolicie katolickich (7,6\%) oraz ponad sześciokrotnie częstszy niż u badanych, których obydwoje rodzice są prawosławni (3,3\%). Z kolei tożsamość typu A, z silną identyfikacją i walencją, badanych z rodzin mieszanych $(12,2 \%)$ charakteryzuje dwukrotnie rzadziej niż ich kolegów z rodzin jednolitych wyznaniowo (26,7\% rodziny prawosławne, 22,1\% rodziny katolickie). Warto zwrócić uwagę także na to, że typ tożsamości C, z silną identyfikacją w sferze religijnej i jednocześnie słabą walencją, w grupie studentów pochodzących z rodzin mieszanych plasuje się na trzecim miejscu $(14,6 \%)$ i jest to wyraźnie częściej niż u badanych wychowanych w rodzinach jednolitych wyznaniowo (10,0\% - rodziny prawosławne, 5,5\% - rodziny katolickie). Widzimy więc wyraźnie, że wychowanie w rodzinie mieszanej wyznaniowo wiąże się ze zmniejszeniem roli wymiaru religijnego w tożsamości społeczno-kulturowej młodych ludzi.

Analizując tożsamość badanych w sferze religijnej, uwzględniono także strukturę rodziny. Wzięto pod uwagę liczbę rodzeństwa i to, czy młody człowiek był wychowywany przez obydwoje rodziców, czy tylko przez jednego. Rozpocznę od zaprezentowania rozkładu typów tożsamości w zależności od liczby posiadanego rodzeństwa. Liczbę sióstr bądź braci podało 440 badanych, co stanowi 97,1\% wszystkich uczestników badania. Wyniki zaprezentowane poniżej dotyczą właśnie tej grupy. Najliczniejsza grupa studentów pochodziła z rodzin z dwójką dzieci. Prawie połowa $\mathrm{z}$ nich $(47,0 \%)$ zadeklarowała posiadanie tylko jednego brata lub siostry. Co dziewiąty badany (11,6\%) jest jedynakiem. Pozostali $(41,4 \%)$ pochodzą $\mathrm{z}$ rodzin z minimum trojgiem dzieci. Dzisiaj często takie rodziny uznaje się za ro- 
dziny wielodzietne. Tymczasem tylko one zapewniają wyjście poza prostą odtwarzalność pokoleń, gdyż liczba dzieci w tych rodzinach przekracza liczbę rodziców.

Spójrzmy zatem, jak liczba dzieci w rodzinie różnicowała częstotliwość występowania poszczególnych wyodrębnionych typów tożsamości (tab. 5).

Tabela 5. Występowanie wyodrębnionych typów tożsamości a liczba rodzeństwa badanego

\begin{tabular}{|c|c|c|c|c|c|c|}
\hline \multirow{3}{*}{ Typ tożsamości } & \multicolumn{6}{|c|}{ Badani $(N=440)$} \\
\hline & \multicolumn{2}{|c|}{ brak rodzeństwa } & \multicolumn{2}{|c|}{$\begin{array}{l}\text { jeden brat lub } \\
\text { siostra }\end{array}$} & \multicolumn{2}{|c|}{$\begin{array}{l}\text { dwójka rodzeństwa } \\
\text { lub więcej }\end{array}$} \\
\hline & Liczba & $\%$ & Liczba & $\%$ & Liczba & $\%$ \\
\hline $\begin{aligned} \text { Typ A - } & \text { silna identyfikacja i silna } \\
& \text { walencja w sferze religijnej }\end{aligned}$ & 8 & 15,69 & 38 & 18,36 & 43 & 23,63 \\
\hline $\begin{aligned} \text { Typ B - } & \text { silna identyfikacja i prze- } \\
& \text { ciętna walencja w sferze } \\
& \text { religijnej }\end{aligned}$ & 6 & 11,76 & 37 & 17,87 & 39 & 21,43 \\
\hline $\begin{aligned} \text { Typ C - } & \text { silna identyfikacja i słaba } \\
& \text { walencja w sferze religijnej }\end{aligned}$ & 3 & 5,88 & 20 & 9,66 & 8 & 4,40 \\
\hline $\begin{aligned} & \text { Typ D - } \text { przeciętna identyfikacja } \\
& \text { i silna walencja w sferze } \\
& \text { religijnej }\end{aligned}$ & 5 & 9,80 & 15 & 7,25 & 22 & 12,09 \\
\hline $\begin{aligned} \text { Typ E - } & \text { przeciętna identyfikacja } \\
& \text { i przeciętna walencja w sfe- } \\
& \text { rze religijnej }\end{aligned}$ & 5 & 9,80 & 23 & 11,11 & 23 & 12,64 \\
\hline $\begin{aligned} \text { Typ F - } & \text { przeciętna identyfikacja } \\
& \text { i słaba walencja w sferze } \\
& \text { religijnej }\end{aligned}$ & 5 & 9,80 & 21 & 10,14 & 13 & 7,14 \\
\hline $\begin{aligned} \text { Typ G - } & \text { słaba identyfikacja i silna } \\
& \text { walencja w sferze religijnej }\end{aligned}$ & 3 & 5,88 & 5 & 2,42 & 6 & 3,30 \\
\hline $\begin{aligned} \text { Typ H - } & \text { słaba identyfikacja i prze- } \\
& \text { ciętna walencja w sferze } \\
& \text { religijnej }\end{aligned}$ & 7 & 13,73 & 15 & 7,25 & 10 & 5,49 \\
\hline $\begin{aligned} \text { Typ I - } & \text { słaba identyfikacja i walen- } \\
& \text { cja w sferze religijnej }\end{aligned}$ & 9 & 17,65 & 33 & 15,94 & 18 & 9,89 \\
\hline Ogółem & 51 & 100,00 & 207 & 100,00 & 182 & 100,00 \\
\hline
\end{tabular}

Źródło: badania własne

Zgodnie z oczekiwaniami silna tożsamość $\mathrm{w}$ wymiarze religijnym częściej cechowała badane osoby pochodzące $\mathrm{z}$ rodzin $\mathrm{z}$ trojgiem i większą liczbą dzieci. W tej podgrupie prawie co czwarty student $(23,6 \%)$ cechował się występowaniem 
tożsamości typu A - z silną identyfikacją i walencją kulturową w sferze religijnej. To prawie o 8 punktów procentowych więcej niż wynik uzyskany dla tego samego typu tożsamości w grupie jedynaków (15,7\%). Konsekwentnie u osób z jedną siostrą bądź bratem odsetek występowania tożsamości typu A mieścił się pomiędzy dwiema wcześniej wymienionymi podgrupami i wynosił 18,4\%. Można więc skonstatować, że częstotliwość występowania tożsamości z silną identyfikacją i silną walencją $\mathrm{w}$ wymiarze religijnym rośnie wraz ze wzrostem liczby dzieci w rodzinie. Podobna tendencja dotyczy także tożsamości typu B (silna identyfikacja i przeciętna walencja kulturowa). Przy czym rozpiętość jest tu jeszcze większa i wynosi prawie 10 punktów procentowych (11,8\% - jedynacy, $21,4 \%$ - studenci pochodzący z rodzin $\mathrm{z}$ minimum trójką dzieci). Spójny obraz uzyskano w przypadku analizy częstości występowania tożsamości religijnej typu I (słaba identyfikacja i walencja). Taki typ tożsamości stwierdzono prawie dwukrotnie częściej u jedynaków $(17,7 \%)$ niż u badanych pochodzących z rodzin wielodzietnych $(9,9 \%)$. Podobny układ dotyczy też zbliżonego typu tożsamości - typu oznaczonego literą $\mathrm{H}$, charakteryzującego się słabą identyfikacją i przeciętną walencją kulturową w sferze religijnej. Częstotliwość pojawiania się takiego typu tożsamości jest ponad dwukrotnie wyższa wśród jedynaków (13,7\%) niż wśród badanych deklarujących posiadanie więcej niż dwojga rodzeństwa. Na zakończenie analizowania rozkładu typów tożsamości ze względu na liczbę dzieci w rodzinie badanego zwróćmy uwagę, że wyrazista tożsamość $\mathrm{w}$ wymiarze religijnym $\mathrm{z}$ silną identyfikacją i walencją (typ A) w rodzinach wielodzietnych występuje ponad dwukrotnie częściej $(23,6 \%)$ niż w rodzinach z jednym dzieckiem $(9,9 \%)$. Z kolei wśród jedynaków jest inaczej. Tutaj dominuje typ tożsamości I - ze słabą identyfikacją i walencją kulturową w sferze religijnej (17,7\%). Jest on w tej grupie nieznacznie częstszy niż typ tożsamości oznaczony literą A (silna identyfikacja i walencja), który stwierdzono u 15,7\% jedynaków. Na podstawie uzyskanych rezultatów można stwierdzić, że struktura rodzin badanych studentów w zakresie liczby rodzeństwa wyraźnie różnicuje tożsamość społeczno-kulturową w wymiarze religijnym. Im więcej dzieci $\mathrm{w}$ rodzinie, tym większe jest prawdopodobieństwo pojawienia się u młodych ludzi tożsamości typu A, z silną identyfikacją religijną oraz silną walencją, czyli wysokim poziomem rozpoznawalności kryterialnych atrybutów tożsamościowych z zakresu tożsamości religijnej. Z kolei prawdopodobieństwo pojawienia się tożsamości ze słabą identyfikacją i walencją kulturową w sferze religijnej jest tym większe, im mniej dzieci w rodzinie.

Badanych pytano o ich ocenę relacji z rodzicami w okresie dorastania. Mogli oni ocenić stosunki z rodzicami na skali: bardzo złe, złe, przeciętne, dobre i bardzo dobre. Jeżeli chodzi o relacje z matką, uczestniczący w badaniu studenci w zdecy- 
dowanej większości uznali je za bardzo dobre (57,2\%). Prawie co trzeci uczestnik badań $(30,1 \%)$ oszacował relacje z matką jako dobre, co dziewiąty (10,9\%) jako przeciętne. Jedynie niewielka grupka badanych uznała relacje $\mathrm{z}$ matką $\mathrm{w}$ okresie dojrzewania jako złe $(1,1 \%)$ lub bardzo złe $(0,7 \%)$.

Wyraźne zróżnicowanie (wykres 2) zobaczymy zwłaszcza w częstotliwości występowania typu tożsamości z silną identyfikacją oraz walencją kulturową w wymiarze religijnym (typ A). Ten typ stwierdzono u prawie co czwartego badanego uznającego relacje z matką za bardzo dobre (23,6\%). Dla porównania, wśród badanych odczuwających relacje z matką jako przeciętne, typ tożsamości oznaczony literą A występował prawie czterokrotnie rzadziej (8,2\%). Trudno uwzględniać wyniki dotyczące grupy badanych określających relacje z matką jako złe bądź bardzo złe ze względu na ich znikomą liczebność (odpowiednio 5 i 3 badanych studentów).

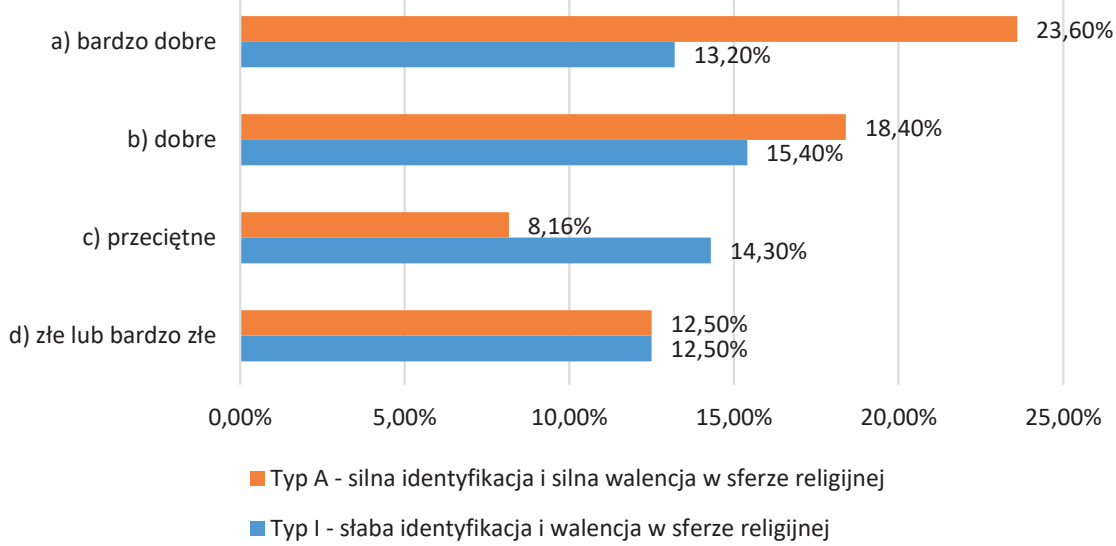

Wykres 2. Udział skrajnych typów tożsamości (A, I) w spektrum tożsamości badanych z uwzględnieniem deklarowanych przez nich relacji z matką

Uwaga: odsetki nie sumują się do 100\%, ponieważ na wykresie zostały uwzględnione tylko dwa typy tożsamości.

Źródło: badania własne

Jeszcze większe różnice odnajdziemy w przypadku uwzględnienia oceny przez badanego relacji z ojcem. Trzeba od razu zauważyć, że stosunki z ojcem są przez badanych oceniane wyraźnie gorzej niż z matką. Jako bardzo dobre relacje z ojcem w okresie dojrzewania oceniło zaledwie 39,8\% badanych. Przypomnijmy, że dla matek ten wskaźnik był o 18 punktów procentowych wyższy i wynosił 57,2\%. Co trzeci uczestniczący w badaniu opisuje relacje z ojcem - w interesującym nas najbardziej okresie adolescencji - jako raczej dobre (33,9\%). Tutaj wynik jest zbliżony 
do tego uzyskanego w odniesieniu do matek $(30,1 \%)$. Natomiast prawie dwukrotnie częściej - 18,4\% w przypadku ojców i 10,9\% w przypadku matek - studenci oceniali relacje z nimi jako przeciętne. Jednak najbardziej spektakularna różnica dotyczy dolnej części zastosowanej skali, czyli odpowiedzi badanych uznających, że stosunki z ojcem $\mathrm{w}$ okresie dojrzewania były złe lub bardzo złe. W przypadku matek takie odpowiedzi wystąpiły u zaledwie 1,8\% procenta badanych. U ojców wskaźnik jest aż czterokrotnie wyższy i wynosi 7,9\%. 4,5\% badanych opisało relacje z ojcem jako złe, a 3,4\% jako bardzo złe. Obraz relacji z matką w okresie dojrzewania - tak ważnym dla budowania tożsamości - rysuje się więc w zdecydowanie jaśniejszych barwach niż w odniesieniu do ojców. Spójrzmy zatem jak oszacowanie przez uczestniczących w badaniu studentów relacji z ojcem różnicowało występowanie u nich skrajnych typów tożsamości w wymiarze religijnym (wykres 3).

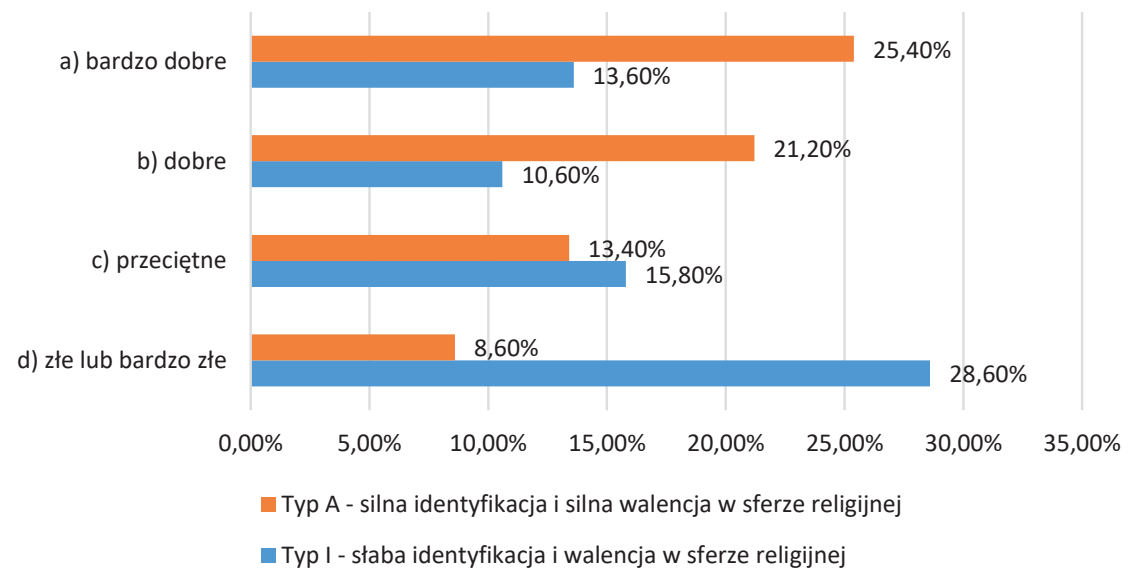

Wykres 3. Udział skrajnych typów tożsamości (A, I) w spektrum tożsamości badanych z uwzględnieniem deklarowanych przez nich relacji z ojcem

Uwaga: odsetki nie sumują się do $100 \%$, ponieważ uwzględnione zostały wybrane tylko dwa typy tożsamości.

Źródło: badanie własne

Zauważmy wyraźnie liniową zależność między szacowaniem relacji z ojcem a częstotliwością występowania tożsamości typu A (silna identyfikacja i walencja kulturowa w sferze religijnej). Wraz z uznawaniem kontaktów z ojcem w okresie dojrzewania za lepsze i lokowaniem odpowiedzi na wyższych punktach skali rośnie także odsetek osób z tożsamością typu A. Wśród badanych oceniających swoje relacje z ojcem jako złe lub bardzo złe częstość występowania tego typu tożsamości jest trzykrotnie niższa $(8,6 \%)$ niż wśród badanych, którzy swoje kontakty z ojcem w okresie dojrzewania opisują jak bardzo dobre (25,4\%). Zwróćmy uwagę, 
że wskaźnik występowania tożsamości typu A w grupie studentów opisujących relacje jako bardzo dobre z matką (23,6\%), jak i ojcem (25,4\%) są bardzo zbliżone i dotyczą co czwartego badanego. Podobnie jest także w innych punktach zastosowanej skali.

Najbardziej istotna różnica dotyczy jednak częstotliwości występowania tożsamości typu I (słaba zarówno identyfikacja, jak i walencja kulturowa w sferze religijnej). Taki typ tożsamości stwierdzano nawet nieco częściej niż u co czwartego badanego studenta (28,6\%), który swoje relacje z ojcem w okresie dojrzewania opisywał jak złe lub bardzo złe. To ponad dwukrotnie częściej niż w grupie studentów szacujących relacje z ojcem jako bardzo dobre (13,6\%). Widzimy więc, że o ile rozkład występowania tożsamości typu A w zależności od oceny relacji z rodzicem w okresie dojrzewania jest bardzo zbliżony dla matek i ojców w odniesieniu do tożsamości typu A, to w przypadku tożsamości typu I jest zupełnie inaczej. Konkludując, można stwierdzić, że postrzeganie przez badanych relacji z rodzicami w okresie adolescencji ma duże znaczenie dla kształtowania ich tożsamości w sferze religijnej. Zauważamy ogólną tendencję do częstszego pojawiania się typu tożsamości z silną identyfikacją i walencją w sferze religijnej wśród badanych lepiej oceniających swoje relacje z rodzicami. Z kolei z występowaniem tożsamości ze słabą identyfikacją i walencją w sferze religijnej bardzo wyraziście wiąże się deklaracja dotycząca relacji z ojcem. Prawdopodobieństwo wystąpienia tożsamości typu I bardzo wyraźnie podwyższa ocenianie relacji z ojcem jako złej lub bardzo złej.

Uzupełnieniem obrazu zaprezentowanego powyżej był rozkład częstotliwości występowania skrajnych typów tożsamości społeczno-kulturowej w wymiarze religijnym w zależności od odpowiedzi przez badanych na pytania, czy matka bądź ojciec poświęcali im dostatecznie dużo czasu w dzieciństwie. Odpowiadając, badani wykorzystywali klasyczną skalę Likerta: od zdecydowanie nie, poprzez raczej nie, trudno powiedzieć, raczej tak, aż po zdecydowanie tak. Rozkład wyników obejmujący opinie dotyczące matek zaprezentowany jest na wykresie 4 .

Okazuje się, że silna tożsamość społeczno-kulturowa w wymiarze religijnym, reprezentowana przez typ A, występuje najczęściej wówczas, kiedy badani na postawione pytanie odpowiadają zdecydowanie pozytywnie. Wśród odpowiadających zdecydowanie tak na pytanie, czy matka poświęcała Ci dostateczną ilość czasu w dzieciństwie, co czwarty uczestniczący w badaniu student (24,9\%) legitymuje się tożsamością typu A. W przypadku wybierania odpowiedzi raczej tak częstotliwość pojawiania się takiego typu tożsamości znacznie spada i dotyczy już tylko co dziewiątego uczestnika badań (11,3\%). Warto podkreślić, że silna tożsamość religijna reprezentowana przez typ A nie wystąpiła w ogóle w sytuacji, kiedy badani uznawali, że matka nie poświęcała im w dzieciństwie dostatecznie dużo czasu. 


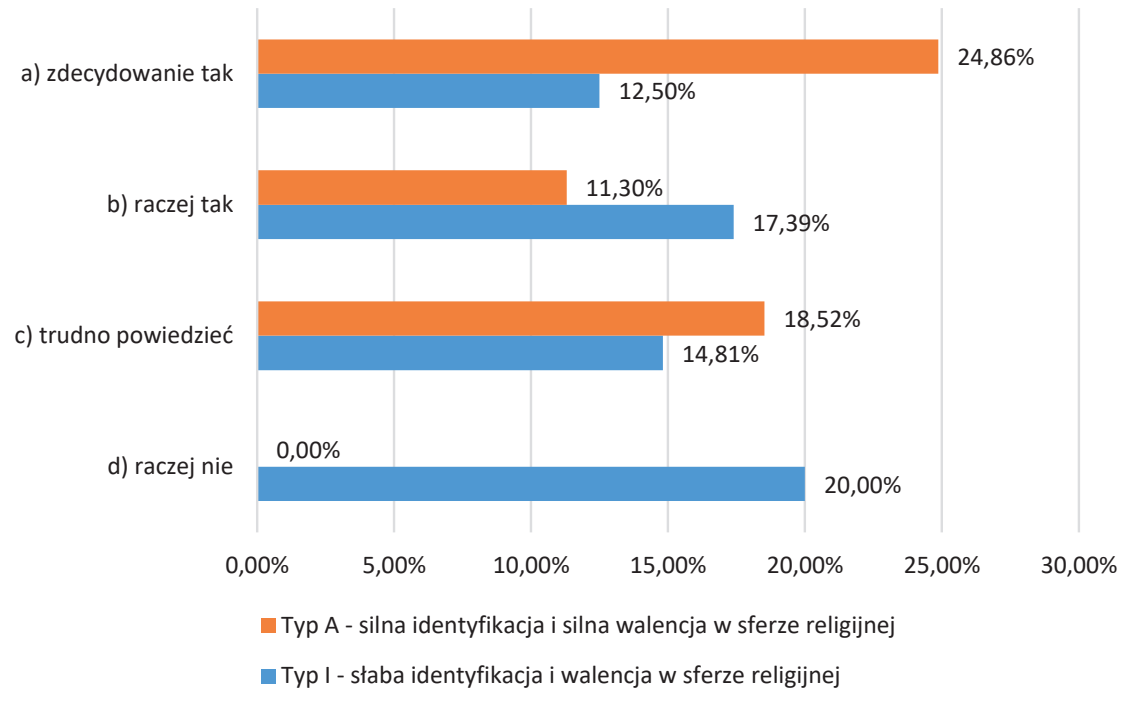

Wykres 4. Rozkład skrajnych typów tożsamości (A, I) wśród badanych z uwzględnieniem ich odpowiedzi na pytanie: czy matka poświęcała Ci dostateczną ilość czasu w dzieciństwie?

Uwaga: odsetki nie sumują się do $100 \%$, ponieważ uwzględnione zostały wybrane tylko dwa typy tożsamości.

Źródło: badanie własne

Ciekawy i logicznie komplementarny obraz w stosunku do wyżej zaprezentowanego stwierdzamy w przypadku analizy rozkładu częstotliwości występowania tożsamości typu I, ze słabą identyfikacją i walencją kulturową w sferze religijnej. Taki typ tożsamości pojawia się u co piątego badanego (20\%), który uznawał, że matka raczej nie poświęcała mu dostatecznie dużo czasu w dzieciństwie. Wśród studentów zadowolonych z ilości czasu przeznaczanego na kontakt z nimi przez matkę (zdecydowanie tak) odsetek dysponujących tożsamością typu I jest prawie o połowę niższy i wynosi $12,5 \%$. Chociaż mamy tu do czynienia jedynie z opinią badanego, to jednak warto podkreślić wyraźną zależność między częstotliwością występowania skrajnych typów tożsamości społeczno-kulturowej w wymiarze religijnym (typy A oraz I) od tego, jak wiele czasu w dzieciństwie poświęcała badanemu matka.

Kolejnym uwzględnionym w badaniu czynnikiem związanym z rodzicami było postrzeganie przez uczestników badania poziomu ich religijności. Spójrzmy najpierw, jaki obraz ukształtował się w odniesieniu do matek badanych. Okazuje się, że najczęściej wybieranym punktem skali była odpowiedź poziom wysoki (38,3\%). Jako bardzo wysoki poziom religijności swoich matek opisywał dokładnie co czwarty badany $(25,0 \%)$. Na drugim krańcu skali odpowiedzi były zdecydowanie rzadsze. $7,2 \%$ badanych postrzegało poziom religijności matek jako niski, a 3,1\% jako bar- 
dzo niski. Warto zauważyć, że co dziesiąty badany nisko bądź bardzo nisko ocenia religijność swoich matek. Jak te oszacowania różnicują występowanie u badanych skrajnych typów tożsamości społeczno-kulturowej w wymiarze religijnym?

Jak widzimy na wykresie 5, istnieje bardzo silny związek między częstotliwością występowania u badanych skrajnych typów tożsamości a szacowaniem przez nich poziomu religijności matek. Zależność ta ma wybitnie liniowy charakter. Prawie co trzeci uczestniczący w badaniu student (31\%) charakteryzujący się tożsamością typu A - z silną identyfikacją i walencją kulturową w sferze religijnej opisuje poziom religijności swej matki jako bardzo wysoki. W tej podgrupie badanych wraz ze zmniejszającym się oszacowaniem religijności matki spada odsetek stwierdzanych tożsamości typu A. Warto zauważyć, że takiego typu tożsamości nie stwierdzono wśród badanych opisujących poziom religijności matki jako bardzo niski. Z kolei właśnie w tej podgrupie aż co drugi uczestniczący w badaniu (50,0\%) cechuje się występowaniem skrajnego typu tożsamości (typ I) ze słabą identyfikacją i walencją kulturową w sferze religijnej. Widzimy, że im wyżej badani oceniają religijność swoich matek, tym mniejsze jest prawdopodobieństwo pojawiania się u nich słabej tożsamości społeczno-kulturowej w wymiarze religijnym. Taka tożsamość cechuje zaledwie 3,5\% badanych opisujących poziom religijności swych matek jako bardzo wysoki.

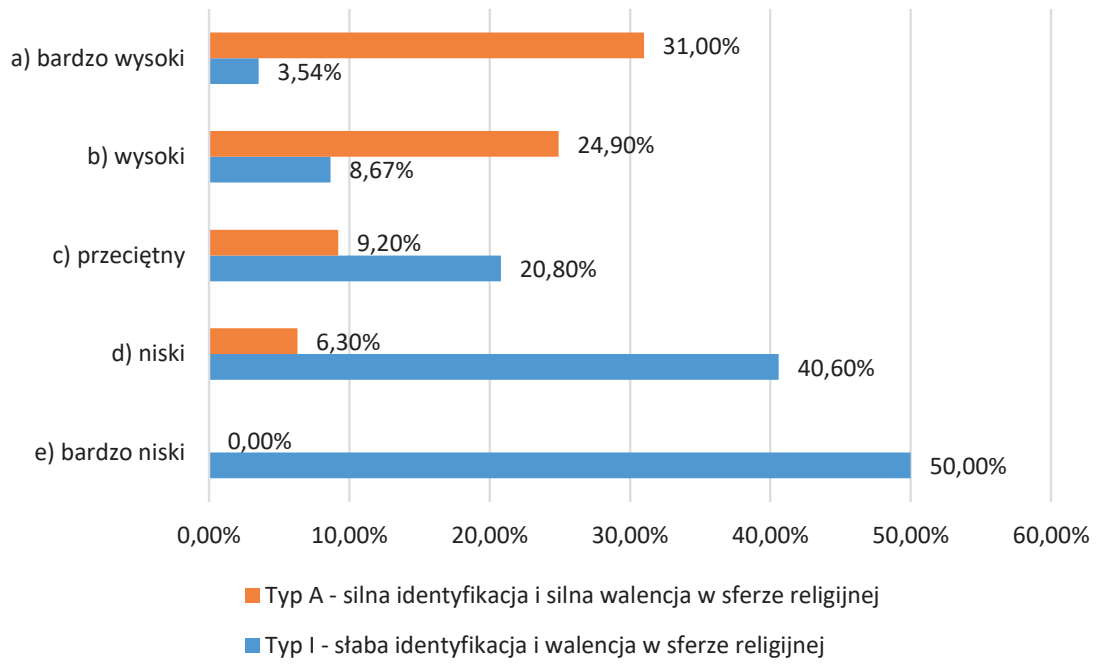

Wykres 5. Udział skrajnych typów tożsamości (A, I) w spektrum tożsamości badanych z uwzględnieniem ich opinii na temat poziomu religijności matek

Uwaga: odsetki nie sumują się do 100\%, ponieważ uwzględnione zostały wybrane tylko dwa typy tożsamości. 
Bardzo podobny rozkład typów tożsamości widzimy także wówczas, gdy uwzględnimy opinie badanych na temat religijności ich ojców (wykres 6).

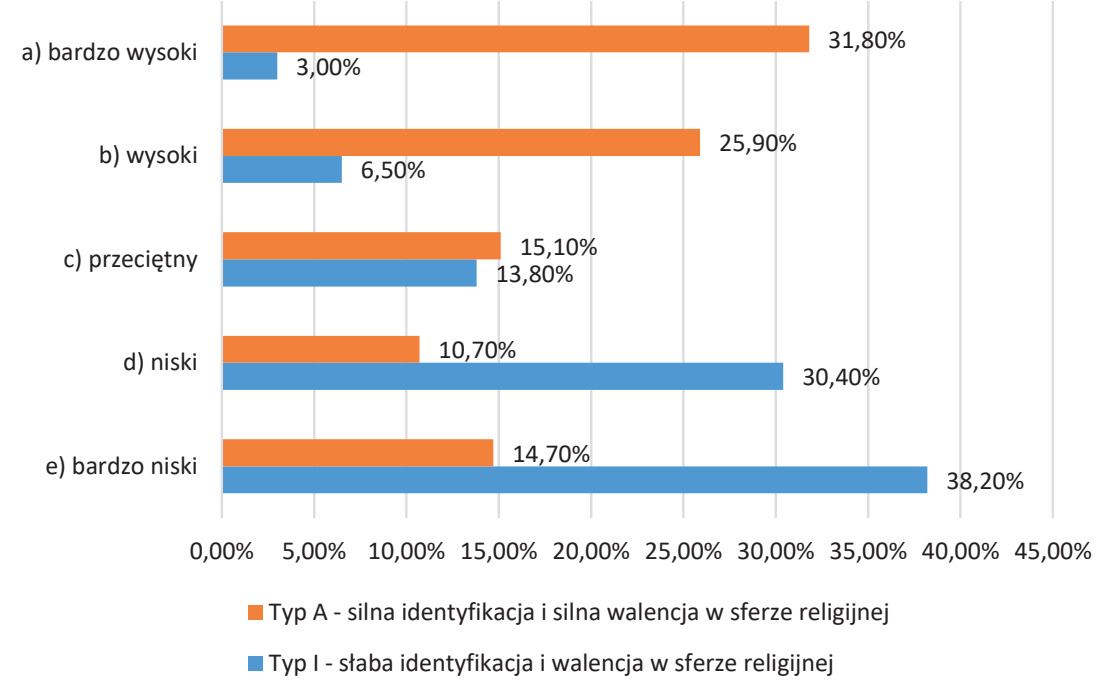

Wykres 6. Udział skrajnych typów tożsamości (A, I) w spektrum tożsamości badanych z uwzględnieniem ich opinii na temat poziomu religijności ojców

Uwaga: odsetki nie sumują się do $100 \%$, ponieważ uwzględnione zostały wybrane tylko dwa typy tożsamości.

Źródło: badanie własne

Prawdopodobieństwo wystąpienia tożsamości ze słabą identyfikacją i walencją kulturową w sferze religijnej rośnie wraz z tym, im niżej badani oceniają religijność swoich ojców. Wśród badanych wyrażających opinię, że poziom religijności ich ojców jest bardzo niski odsetek badanych z typem tożsamości oznaczonym literą I jest aż prawie trzynastokrotnie wyższy $(38,2 \%)$ niż wśród uczestników badania szacujących poziom religijności ojców jako bardzo wysoki (3,0\%). Inaczej niż w przypadku oceniania przez badanych religijności matek, w przypadku ojców występowanie typu tożsamości z silną identyfikacją i walencją (typ A) nie ma już liniowego charakteru, a to z powodu sytuacji, w której badani szacują poziom religijności ojca jako bardzo niski. Wśród nich aż co siódmego $(14,7 \%)$ cechuje silna tożsamość społeczno-kulturowa w wymiarze religijnym (typ A). Przypomnijmy, że u badanych, którzy bardzo nisko oceniają religijność matki, taki typ tożsamości nie wystąpił w ogóle. Mimo tej jedynej znaczącej różnicy można stwierdzić, że postrzeganie przez badanych studentów religijności ich rodziców stanowi bardzo znaczący czynnik różnicujący rozkład skrajnych typów tożsamości społeczno-kulturowej w wymiarze religijnym. 


\section{Konkluzje}

Zgodnie z przewidywaniami uwarunkowania rodzinne mają bardzo duże znaczenie w formowaniu tożsamości-społecznej późnych adolescentów. Mimo ponownego pojawienia się w Polsce religii w szkole w latach 90. minionego wieku, to właśnie rodzina nadal pozostaje główną przestrzenią socjalizacji religijnej. Przeprowadzone badania dowiodły, że o typie tożsamości społeczno-kulturowej studentów w znaczącej mierze decyduje status społeczno-kulturowy rodziców oraz relacje zachodzące między rodzicami a dziećmi. Dodajmy, że są to relacje widziane oczyma dorosłych już dzieci. Nie bez znaczenia jest także zaangażowanie religijne rodziców zarejestrowane w świadomości ich dzieci. Klasyczny mechanizm modelowania znajduje tu wyraziste zastosowanie. Rodzice są postrzegani jako religijni zdecydowanie częściej przez badanych charakteryzujących się silną identyfikacją religijną i wysokim poziomem kompetencji w sferze chrześcijańskiej kultury symbolicznej. Przedstawione tu wyniki stanowią część przygotowywanej do druku monografii. Jednak nawet wycinkowy obraz nasuwa szereg refleksji ważnych tak dla adeptów pedagogiki i naukowców zajmujących się podobną problematyką, jak i dla rodziców.

\section{Bibliografia}

Danilewicz W. (2011), Tożsamość rodzinna „ponad granicami” w świetle koncepcji transnarodowej przestrzeni społecznej, Pogranicze. Studia Społeczne, t. XVII, s. 30-42.

Dyczewski L. (2003), Rodzina twórca i przekazicielem kultury, Lublin.

Edgell P. (2006), Religion and Family in a Changing Society, Princeton.

Hunsberger B., Brown L.B. (1984), Religious Socialization, Apostasy, and the Impact of Family Background, Journal for the Scientific Study of Religion, 23(3), s. 239-251.

Kłoskowska A. (1994), Kultury narodowe u korzeni, Warszawa.

Lopez A.B., Huynh V.W., Fuligni A.J. (2011), A Longitudinal Study of Religious Identity and Participation During Adolescence, Child Development, 82(4), s. 1297-1309.

Merton R.K. (2002), Teoria socjologiczna i struktura społeczna, Warszawa.

Nikitorowicz J. (1994), Pogranicze, tożsamość, edukacja międzykulturowa, Białystok.

Sobecki M. (2016), Rodzinne uwarunkowania kształtowania tożsamości, Pedagogika Społeczna, nr 1 (59), s. 125-136.

Wilk J. (1987), Znaczenie pierwszych doświadczeń dla religijnego wychowania małego dziecka $w$ rodzinie, Lublin.

Wilk J. (2016), Pedagogika rodziny, Lublin. 